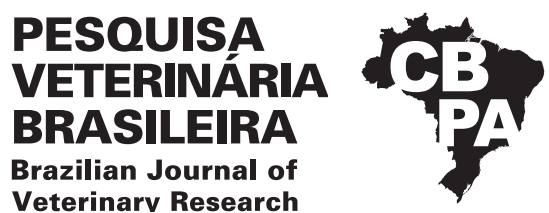

Pesq. Vet. Bras. 40(3):176-180, March 2020 DOI: 10.1590/1678-5150-PVB-6049

Original Article

ISSN 0100-736X (Print)

ISSN 1678-5150 (Online)

\title{
Clinical management of dogs with presumptive diagnosis of cervical intervertebral disc disease: 78 cases $(2006-2017)^{1}$
}

\author{
Raquel Baumhardt ${ }^{2}$, Angel Ripplinger ${ }^{2}$, Graciane Aiello², \\ Marcelo L. Schwab르, Denis A. Ferrarin ${ }^{2}$, Mathias R. Wrzesinski², \\ Samanta S. Moro ${ }^{3}$ and Alexandre Mazzanti* ${ }^{4 *}$
}

\begin{abstract}
Baumhardt R., Ripplinger A., Aiello G., Schwab M.L., Ferrarin D.A., Wrzesinski M.R., Moro S.S. \& Mazzanti A. 2020. Clinical management of dogs with presumptive diagnosis of cervical intervertebral disc disease: 78 cases (2006-2017). Pesquisa Veterinária Brasileira 40(3):176-180. Departamento de Clínica de Pequenos Animais, Centro de Ciências Rurais, Universidade Federal de Santa Maria, Av. Roraima 1000, Camobi, Santa Maria, RS 97105-900, Brazil. E-mail: alexamazza@yahoo.com.br

This study aimed to identify dogs with a presumptive diagnosis of cervical intervertebral disc disease (IVDD; C1-C5 or C6-T2) submitted to clinical management and evaluate the outcome. This study also aimed to demonstrate the age, sex, and treatment response according to the neurological degree, and verify whether those factors could potentially influence the outcome. The data were obtained from patients with a neurological dysfunction, admitted at the Veterinary Hospital from January 2006 to March 2017. In addition to patient records, the tutors answered a questionnaire related to the success of therapy. A hundred and seventyseven neurological records were evaluated, and 78 were included in the study according to the inclusion criteria. The most frequent breeds were Dachshunds, followed by mixed-breed dogs. Regarding the neurological dysfunction degree, 58.97\% presented grade I (only neck pain), 25.64\% were grade II (ambulatory tetraparesis), and 15.38\% grade III (nonambulatory tetraparesis). Absolute and partial space rest were performed in $75.64 \%$ and $24.36 \%$ of the cases, respectively. The minimum rest time was one week and could come up to four weeks. Most dogs were small-sized $(\leq 15 \mathrm{~kg})$. The recovery was satisfactory in $87.17 \%$ of dogs and unsatisfactory in $12.83 \%$. Regarding recurrence, we observed that $10.3 \%$ of dogs presented satisfactory recovery. The clinical treatment for dogs with cervical IVDD can be indicated with adequate clinical response to dysfunction degrees ranging from I to III, either at rest or in restricted space and with a low rate of relapse.
\end{abstract}

INDEX TERMS: Clinical management, dogs, diagnosis, cervical, intervertebral disc disease, IVDD, cage rest, extrusion, protrusion, clinics.

\footnotetext{
${ }^{1}$ Received on July 18, 2019.

Accepted for publication on August 20, 2019.

${ }^{2}$ Graduate Program in Veterinary Medicine, Serviço de Neurologia e Neurocirurgia Veterinária (SNNV), Universidade Federal de Santa Maria (UFSM), Avenida Roraima 1000, Camobi, Santa Maria, RS 97105-900, Brazil.

${ }^{3}$ Curso de Medicina Veterinária, Centro de Ciências Rurais (CCR), Universidade Federal de Santa Maria (UFSM), Avenida Roraima 1000, Camobi, Santa Maria, RS 97105-900, Brazil.

${ }^{4}$ Departamento de Clínica de Pequenos Animais, Serviço de Neurologia e Neurocirurgia Veterinária (SNNV), Centro de Ciências Rurais (CCR), Universidade Federal de Santa Maria (UFSM), Avenida Roraima 1000, Camobi, Santa Maria, RS 97105-900, Brazil. *Corresponding author: alexamazza@yahoo.com.br
}

RESUMO.- [Tratamento clínico de cães com diagnóstico presuntivo de doença do disco intervertebral cervical: 78 casos (2006-2017).] 0 objetivo desse estudo foi identificar cães com diagnóstico presuntivo de doença do disco intervertebral cervical (DDIV; C1-C5 ou C6-T2) submetidos ao tratamento clínico e avaliar a resposta a terapia instituída e o índice de recidiva. Esse estudo também visou demonstrar a idade, o gênero e a resposta ao tratamento de acordo com o grau neurológico, a fim de verificar se esses parâmetros podem ser utilizados como fatores prognósticos para a evolução clínica desses pacientes. Foram revisados os registros neurológicos 
do Hospital Veterinário Universitário de janeiro de 2006 a março de 2017. Realizaram coleta de dados a partir dos registros e por meio de um questionário respondido pelos tutores. Avaliaram 177 fichas neurológicas de cães e obtidas informações para inclusão no estudo em 78 delas. As raças mais frequentes foram Dachshunds, seguido dos cães sem raça definida. Quanto ao grau de disfunção neurológica, $58,97 \%$ apresentavam grau I (somente dor), 25,64\% estavam em grau II (tetraparesia ambulatória) e 15,38\% em grau III (tetraparesia não ambulatória). 0 repouso absoluto e em espaço restrito foram realizados em $75,64 \%$ e $24,36 \%$ dos casos, respectivamente e com duração de no mínimo uma semana, podendo chegar a mais de quatro semanas. A maioria dos animais era de pequeno porte $(\leq 15 \mathrm{~kg})$. A recuperação foi satisfatória em 87,17\% dos cães e insatisfatória em 12,83\%. Quanto à recidiva, esta foi observada em $10,3 \%$ dos pacientes com recuperação satisfatória. 0 tratamento clínico para cães com DDIV cervical pode ser indicado com adequada resposta clínica para graus de disfunção que variam de I a III, seja em repouso absoluto ou em espaço restrito e com baixo índice de recidiva.

TERMOS DE INDEXAÇÃO: Tratamento clínico, cães, diagnóstico, doença do disco, intervertebral cervical, DDIV, repouso absoluto, extrusão, protrusão, caninos, clínica.

\section{INTRODUCTION}

Intervertebral disc disease (IVDD) is a common neurological condition in dogs (Fluehmann et al. 2006, Ingram et al. 2013), occurring in the cervical region between $12.9 \%$ and 25.4\% of cases (Goggin et al. 1970, Gage 1975, Chaves et al. 2014). It affects dogs of any breed and size, with the Dachshunds and Beagles being the most prevalent. Its average age of occurrence in the cervical region varies from six to eight years (Russell \& Griffths 1968, Denny 1978, Cherrone et al. 2004, Levine et al. 2007, Ryan et al. 2008, Hillman et al. 2009, Santini et al. 2010, Schmied et al. 2011), for both extrusion and protrusion (Schmied et al. 2011). The minimum and maximum ages reported by Hakozaki et al. 2015 was one and 16 years, respectively, for chondrodystrophic an non-chondrodystrophic breeds.

Intervertebral disc extrusion (Hansen type I) or intervertebral disc protrusion (Hansen type II) may result in spinal cord compression with subsequent spinal cord compression, the protrusion being more frequent than the extrusion in the cervical region (Cherrone et al. 2004). Spinal hyperesthesia is the most reported clinical sign (Dallman et al. 1992, Cherrone et al. 2004, Ryan et al. 2008, Santini 2010). However, more severe signs such as proprioceptive 4-limb ataxia, ambulatory or non-ambulatory tetraparesis, never root signature in the affected thoracic limb, and tetraplegia are also described (Russell \& Griffths 1968, Denny 1978, Seim \& Prata 1982, Morgan et al. 1992, Tomlison 1996, Beal et al. 2001, Cherrone et al. 2004, Hillman et al. 2009). Nociception loss and breathing difficulty may occur but are rarely reported (Beal et al. 2001, Hillman et al. 2009).

Treatment for cervical IVDD can be clinical or surgical (Olby 2014). Clinical treatment consists of absolute cage rest between two and six weeks; this time would be the minimum necessary for annulus fibrous repair (Tipold et al. 2010, Dewey \& Da Costa 2016) and is mainly indicated for dogs in grades I and II of neurological dysfunction (Tipold et al. 2010). Associated with rest, opioid analgesics, muscle relaxants, steroidal or non-steroidal anti-inflammatory drugs, and physical therapy may be used (Sharp \& Wheeler 2005, Brisson 2010). Surgery is the treatment of choice for dogs with severe cervical pain, severe neurological disabilities, recurrences or clinical treatment failure, and chronic signs of the disease (Seim \& Prata 1982, Cherrone et al. 2004, Hillman et al. 2009).

Surgical treatment of cervical IVDD is associated with a high rate of anesthetic-surgical complications, (Rossmeisl et al. 2013) with a mortality rate reaching $8 \%$ (Clark 1986, Posner et al. 2014). Some clinicians avoid cervical decompression surgery as much as possible (Hawthorne et al. 1999), and many tutors are discouraged to authorize the surgical procedure, opting for clinical treatment. Despite these facts, studies addressing the clinical treatment evolution of cervical IVDD in dogs are scarce (Russell \& Griffths 1968, Janssens 1985, Levine et al. 2007).

This study aimed to evaluate the response to the clinical treatment instituted, the recurrence rate, and possible prognostic factors of dogs with a presumptive diagnosis of cervical IVDD. This study also aimed to demonstrate age, gender, and response to treatment according to neurological grade, in order to use these parameters as prognostic factors for the clinical evolution of these patients.

\section{MATERIALS AND METHODS}

Neurological records of a veterinary hospital were reviewed from January 2006 to March 2017. Only dogs with a presumptive diagnosis of IVDD in the C1-C5 and C6-T2 spinal segments were included. The presumptive diagnosis was defined by history, breed, age, clinical signs, neurological examination, plain radiography, myelography or computed tomography (Dewey \& Da Costa 2016). In all dogs, serology tests were performed to exclude infectious diseases (toxoplasmosis, neosporosis and distemper). Each record was reviewed and certified that there were no other (non-neurological) conditions that could interfere with the results of the neurological exam.

Data on breed, age, sex, and neurological dysfunction degree at the time of examination were collected from neurological records. The other information was obtained by telephone contact with the tutors. The neurological dysfunction degree was rated from I to $\mathrm{V}$, where: I) only pain on palpation of the cervical spine; II) ambulatory tetraparesis; III) non-ambulatory tetraparesis; IV) tetraplegia with intact deep pain perception caudal to the lesion site; V) tetraplegia without deep pain perception caudal to the lesion site (Kranenburg et al. 2013). The dogs were distributed amoung age groups up to three years old; four to six years old; seven to nine years old; and greater than or equal to ten years, like the distribution made by Chaves et al. (2014).

The prescribed clinical treatment by the SNNV consisted of absolute rest in a cage or transport box for a minimum of 30 days. The patient was removed three times a day for urination and defecation using a harness. Steroidal or non-steroidal anti-inflammatory drugs and opioid analgesics were also used.

Tutors of the selected patients were contacted by telephone and answered a two-part questionnaire, including: 1) information before hospital appointment; and 2) information after the appointment.

Data from the first part of the questionnaire were related to the recurrence or absence of signs; duration of clinical signs until the moment of appointment; performing absolute rest (in a cage 
or a transport box) or partial rest in a restricted space, and the evolution of clinical signs until the appointment. Signal recurrence was considered in the presence of previous history of back pain and difficulty walking or climbing obstacles. The duration of clinical signs was classified as: less than or equal to one day; $>1$ and up to 7 days and $>7$ days. Regarding the evolution of clinical signs, the dogs were distributed in: satisfactory - when the dog showed improvement compared to the onset of signs; unsatisfactory - when there was no difference or worsening until appointment at the veterinary hospital. Data from the second part of the questionnaire refer to the treatment indicated by the physcian, and the clinical evolution of the treatment performed. Regarding clinical evolution, they were classified as: satisfactory - dogs that have recovered the ability to walk without hyperesthesia; unsatisfactory - when they did not recover motor function or remained with cervical hyperesthesia. Dogs that had satisfactory recovery were assessed for disease recurrence.

Those cases in which dogs died within a period shorter than two weeks or the tutors opted for euthanasia were excluded. All dogs had an interval of at least three months between the first appointment and the start of the survey; this was the minimum period for evaluation of clinical evolution. Any patient with more than seven days of evolution, who has not had rest before the appointment, was included in the control group (i.e., without rest). The treated group was composed of patients who received the treatment indicated by the physician, i.e., absolute cage rest or partial rest in a restricted space at the tutor's option.

Statistical evaluation was performed using the Chi-square test, and the following variables were evaluated: age, gender, recovery (satisfactory or unsatisfactory), type of treatment (absolute rest, rest in restricted space, or no rest), degree of neurological dysfunction, time of evolution.

\section{RESULTS AND DISCUSSION}

A total of 177 neurological records were evaluated, and 78 dogs with a presumptive diagnosis of cervical IVDD were included. Of this total, $52.56 \%(n=41)$ dogs were male and $47.43 \%(n=37)$ were female. Regarding breed, $39.74 \%$ were Dachshund ( $\mathrm{n}=31), 23.07 \%$ mixed-breed (MB) $(\mathrm{n}=18), 8.97 \%$ Poodle ( $n=7), 6.41 \%$ Lhasa Apso ( $n=5), 5.13 \%$ Yorkshire $(n=4)$, Maltese and Beagle breeds accounted for $2.56 \%$ of the total each $(n=2$ each), the other breeds with one representative each were Australian Cattle Dog, French Bulldog, Chow Chow, Cocker, Brazilian Terrier, Pomeranian Lulu, Alaskan Malamute and Shih Tzu (1.28\% of the total of each breed). The animals' size ranged from small to medium, with body weights from $1.3 \mathrm{~kg}$ to $25 \mathrm{~kg}$ (average $8.51 \mathrm{~kg}$ and median $8.10 \mathrm{~kg}$ ), 71 with weight less than or equal to $15 \mathrm{~kg}$ and seven with a weight between 16 and $25 \mathrm{~kg}$. The animals' age ranged from one year and 11 months to 18 years (average 8.10 and median 8 years). As shown in Table 1, most of the animals in the study were old than four years old. The minimum and maximum age of the animals in this study is in agreement with studies of Schmied et al. (2011) and Hakozaki et al. (2015), where the minimum ages (three and one year old respectively) and maximum (twelve and sixteen year old respectively) are of dogs with cervical disc protrusion and extrusion in both chondrodystrophic and non-chondrodystrophic breeds. Thus, the population studied, regarding the prevalence of sex, age and breed of the patients, was like those found by previously published studies (Levine et al. 2007, Brisson 2010, Santini et al. 2010, Posner et al. 2014, Hakozaki et al. 2015, Schmied et al. 2011).

The recovery of dogs in different age groups and sex had similar proportions (without statistical difference), suggesting that these variables do not interfere with clinical recovery, which is in agreement with Levine et al. (2007). However, Itoh et al. (2008) found a higher sexual predisposition for male dogs in a janpanese study, which may be due to population variation in the region studied.

Tutors reported first time clinical sings in $84.6 \%(n=66)$ of the cases; signs were recurent in $15.38 \%(n=12)$. Tutors have administered anti-inflammatory drugs in 37,17\% (n=29) before the first appointment, while $34.61 \%(n=27)$ have not used it. In 22 (28.2\%) cases, the tutor did not know the answer. The neurological dysfunction degree was defined as grade I for $58.97 \%$ of dogs, grade II for $25.64 \%$ and grade III for $15.38 \%$ (Table 1). No dog with tetraplegia (grade IV or V) was observed. The higher prevalence of severe pain in the neck region in this study has been verified by Cherrone et al. (2004) as the main clinical sign of cervical DDIV.

The low rate of neurological deficits found for IVDD in the cervical region compared to the thoracolumbar region may be related to the greater width of the vertebral canal in the

Table 1. Representation of satisfactory recovery and relapse according to epidemiological variables evaluated in 78 dogs with presumptive diagnosis of cervical IVDD undergoing clinical treatment (2006-2017)

\begin{tabular}{|c|c|c|c|}
\hline Variable & $\begin{array}{c}\text { Number of } \\
\text { dogs } n\end{array}$ & $\begin{array}{c}\text { Satisfactory } \\
\text { recovery n (\%) }\end{array}$ & $\begin{array}{c}\text { Relapse } \\
\text { n (\%) }\end{array}$ \\
\hline \multicolumn{4}{|l|}{ Sex } \\
\hline Female & 37 & $33(89.1)$ & $4(12.1)$ \\
\hline Male & 41 & $35(85.3)$ & $3(8.5)$ \\
\hline \multicolumn{4}{|l|}{ Age } \\
\hline Up to 3 years & 5 & $5(100)$ & - \\
\hline From 4 to 6 years & 22 & $20(90.9)$ & $1(5.00)$ \\
\hline From 7 to 9 years & 25 & $21(84.0)$ & $3(14.2)$ \\
\hline$\geq 10$ years & 26 & $22(84.6)$ & $3(13.6)$ \\
\hline \multicolumn{4}{|l|}{ Duration of clinical signs } \\
\hline$\leq 1$ day & 5 & $5(100)$ & - \\
\hline$>1-7$ days & 34 & $30(88.2)$ & $5(16.6)$ \\
\hline$>7$ days & 39 & $33(84.6)$ & $2(6.06)$ \\
\hline \multicolumn{4}{|l|}{ Neurological dysfunction } \\
\hline Grade I & 46 & $43(93.4)$ & $4(9.3)$ \\
\hline Grade II & 20 & $15(75.0)$ & $2(13.3)$ \\
\hline Grade III & 12 & $10(83.3)$ & - \\
\hline \multicolumn{4}{|l|}{ Treatment } \\
\hline Absolute rest & 59 & $52(88.1)$ & $4(7.6)$ \\
\hline Restricted space rest & 19 & $16(84.2)$ & $3(18.7)$ \\
\hline \multicolumn{4}{|l|}{ Rest duration } \\
\hline 1 week & 7 & $5(71.4)$ & - \\
\hline$>1-3.5$ weeks & 54 & $48(88.8)$ & $4(8.3)$ \\
\hline$\geq 4$ weeks & 17 & $15(88.2)$ & $3(20)$ \\
\hline
\end{tabular}


cervical region, so extruded disc contents need to be larger to severely compromise the spinal cord (Brisson 2010).

When the patients were distributed according to the rest performed before the appointment, 91\% $(n=71)$ of the dogs were not in absolute rest, and of these, 91.55\% $(n=65)$ were in an unsatisfactory state according to tutors. The signal duration was less than or equal to one day for $6.41 \%$ of dogs, $>1$ and up to 7 days for $43.59 \%$, and $>7$ days 50\% (Table 1 ).

After the appointment, $75.64 \%$ of cases complied with the absolute rest indicated, and $24.36 \%$ did not rest according to prescription but kept the dog in a restricted space of one room during the treatment period.

Clinical evolution was satisfactory in $87.17 \%(n=68)$ of dogs and unsatisfactory in $12.82 \%(n=10)$. The 10 dogs that did not recover from clinical treatment (three in grade I, five in grade II and two in grade III) were referred for surgery and confirmed disc extrusion (Hansen type I). Of the 68 dogs with satisfactory recovery, 52 were treated as absolute rest and 16 in restricted space (Table 1 ). There was no significant difference between the two types of rest (absolute or restricted) in the present group of animals studied. Bersan et al. (2017) also described success with clinical treatment involving controlled movements for dogs diagnosed with intervertebral disc foraminal extrusion in the cervical region; this suggests that the simple reduction of movement already allows partial or complete resolution of cervical IVDD. Even so, the authors suggest that the clinical treatment should be made in absolute rest since movement is more limited than rest in a restricted space and less likely to worsen the clinical outcome.

Of the dogs with satisfactory recovery, $10.3 \%(n=7)$ presented recurrence, a percentage lower than that observed by Levine et al. (2007) in which 29 of 43 patients who were submitted to clinical treatment and achieved recovery had recurrence. This may reflect the reduced follow-up time performed in part of the patients in the present study (minimum 3 months).

Table 1 shows the percentage of satisfactory recovery regarding gender, age group, degree of dysfunction, and duration of rest. There was no relationship between satisfactory recovery and the items described above.

The satisfactory response was significantly higher for patients treated with absolute rest $(n=59)$ and partial rest $(n=$ 19) when compared to the control group $(n=39)$, i.e., without absolute rest $(\mathrm{p}<0.05)$. Reduction motion induced by rest is believed to minimize further extrusion of disc material into the spinal canal annulus fibrosus heal, and there is a reduction in the inflammatory reaction caused by extrusion during this rest period (Dewey \& da Costa 2016). Spontaneous regression of disc extrusion has been described in humans (Weber 1983, Saal et al. 1990, Mochida et al. 1998) and is believed to occur in dogs as well (Steffen et al. 2014). Extruded disc material is likely reabsorbed as consequence of the inflammatory reaction and the action of activated macrophages (Haro et al. 1996). Komori et al. (1996) demonstrated in humans that the tendency for spontaneous regression of the herniated disc varied with its anatomical location; this may also be related to the degree of a satisfactory response to clinical treatment in dogs. Such information obtained through careful magnetic resonance imaging evaluations suggests larger studies in dogs with cervical IVDD undergoing clinical treatment so that it can be classified when this treatment is chosen for this species.
One of the limitations of this study was the presumptive diagnosis of IVDD. Levine et al. (2007) used simple radiography and myelography as diagnostic aid methods to exclude other causes such as discospondylitis, meningomyelitis fractures, and neoplasms. Moreover, we requested exams to investigate the main canine infectious diseases, in addition to computed tomography, considered an imaging exam with sensitivity higher than myelography in detecting spinal cord compression by IVDD (Brisson 2010). Even so, magnetic resonance imaging and, more precisely, surgical exploration that will reveal extruded content within the vertebral canal are recommended for the definitive diagnosis of IVDD (Levine et al. 2007). Therefore, one cannot rule out the possibility that some dogs with presumptive diagnosis of IVDD had another neurological disorder.

The clinical relevance of this study was to demonstrate the results of the clinical treatment in dogs with a presumptive diagnosis of cervical IVDD in Brazil and to verify that the recovery rate was satisfactory and with low recurrence when compared to the international literature (Levine et al. 2007). Even though the clinical therapy employed in this study was in line with the literature (Dewey \& Da Costa 2016), tutors who did not follow SNNV guidance and optionally restricted movement (restricted space), the results were also satisfactory even for severe degrees of neurological dysfunction (Table 1).

\section{CONCLUSION}

Clinical treatment can be used in dogs with cervical IVDD with an adequate clinical response for dysfunction degrees ranging from I to III, either in absolute rest or restricted space and with a low recurrence rate. There is no difference in clinical response among dogs of different ages or genders, suggesting no prognostic influence of these factors on recovery.

Conflict of interest statement.- The authors have no competing interests.

\section{REFERENCES}

Beal M.W., Paglia D.T., Griffin G.M., Hughes D. \& King L.G. 2001. Ventilatory failure, ventilator management, and outcome in dogs with cervical spinal disorders: 14 cases (1991-1999). J. Am. Vet. Med. Assoc. 218(10):1598-1602. <http://dx.doi.org/10.2460/javma.2001.218.1598> <PMid:11393372>

Bersan E., McConnell F., Trevail R., Behr S., De Decker S., Volk H.A., Smith P.M. \& Gonçalves R. 2017. Cervical intervertebral foraminal disc extrusion in dogs: clinical presentation, MRI characteristics and outcome after medical management. Vet. Rec. 176(23):597-600. <http://dx.doi.org/10.1136/ vr.102851><PMid:25745084>

Brisson B.A. 2010. Intervertebral disc disease in dogs. Vet. Clin. N. Am., Small Anim. Pract. 40(5):829-258. <http://dx.doi.org/10.1016/j.cvsm.2010.06.001> <PMid:20732594>

Chaves R.O., Beckmann D.V., Santos R.P., Aiello G., Andrades A.O., Baumhardt R., Silveira L.B.\& Mazzanti A. 2014. Doenças neurológicas em cães atendidos no Hospital Veterinário da Universidade Federal de Santa Maria, RS: 1.184 casos (2006-2013). Pesq. Vet. Bras. 34(10):996-1001. <http://dx.doi. org/10.1590/S0100-736X2014001000012>

Cherrone K.L., Dewey C.W., Coates J.R. \& Bergman R.L. 2004. A retrospective comparison of cervical intervertebral disk disease in nonchondrodystrophic large dogs versus small dogs. J. Am. Anim. Hosp. Assoc. 40(4):316-320. <http://dx.doi.org/10.5326/0400316> <PMid:15238562>

Clark D.M. 1986. An analysis of intraoperative and early post operative mortality associated with cervical spinal decompressive surgery in the the dog. J. Am. Anim. Hosp. Assoc. 22:739-744. 
Dallman M.J., Palettas P. \& Bojrab M.J. 1992. Characteristics of dogs admitted for treatment of cervical intervertebral disk disease: 105 cases (1972-1982). J. Am. Vet. Med. Assoc. 200(12):2009-2011. <PMid:1639716>

Denny H.R. 1978. The surgical management of cervical disc protrusions in the dog: a review of 40 cases. J. Small Anim. Pract. 19(5):251-257. <http:// dx.doi.org/10.1111/j.1748-5827.1978.tb05483.x><PMid:661234>

Dewey C. \& Da Costa R.C. 2016. Myelopathies: disorders of the spinal cord, p.329-403. In: Dewey C. \& Da Costa R.C. (Eds), Practical Guide to Canine and Feline Neurology. 3rd ed. Wiley Blackwell, Ames.

Fluehmann G., Doherr M.G. \& Jaggy A. 2006. Canine neurological diseases in a referral hospital population between 1989 and 2000 in Switzerland. J. Small Anim. Pract. 47(10):582-587.<http://dx.doi.org/10.1111/j.1748-5827.2006.00106. $\mathrm{x}><$ PMid:17004950>

Gage E.D. 1975. Incidence of clinical disc disease in the dog. J. Am. Anim. Hosp. Assoc. 11:135-138.

Goggin J.E., Li A. \& Franti C.E. 1970. Canine intervertebral disk disease: characterization by age, sex, breed, and anatomic site of involvement. Am. J. Vet. Res. 31(9):1687-1692.<PMid:5528338>

Hakozaki T., Iwata M., Kanno N., Harada Y., Yogo T., Tagawa M. \& Hara Y. 2015. Carvical intervertebral disk herniation in chondrodystrophoid and nonchonrodystrophoid small-beed dogs: 187 cases (1993-2013). J. Am. Vet. Med. Assoc. 247(12):1408-1411. <http://dx.doi.org/10.2460/ javma.247.12.1408><PMid:26642135>

Haro K., Shinomiya K., Komori H., Okawa A., Saito I., Miyasaka N. \& Furoya K. 1996. Upregulated expression of chemokines in herniated nucleus pulposus resorption. Spine 21(14):1647-1652.<http://dx.doi.org/10.1097/00007632199607150-00006><PMid:8839466>

Hawthorne J.C., Blevins W.E., Wallace L.J., Glickman N. \& Waters D.J. 1999. Cervical vertebral fractures in 56 dogs: a retrospective study. J. Am. Anim. Hosp. Assoc. 35(2):135-146. <http://dx.doi.org/10.5326/15473317-352-135> <PMid: 10102182>

Hillman R.B., Kengeri S.S. \& Waters D.J. 2009. Reevaluation of predictive factors for complete recovery in dogs with nonambulatory tetraparesis secondary to cervical disk herniation. J. Am. Anim. Hosp. Assoc. 45(4):155163. <http://dx.doi.org/10.5326/0450155><PMid:19570897>

Ingram E.A., Kale D.C. \& Balfour R.J. 2013. Hemilaminectomy for thoracolumbar Hansen type I intervertebral disk disease in ambulatory dogs with or without neurologic deficits: 39 cases (2008-2010). Vet. Surg. 42(8):924-931. <http://dx.doi.org/10.1111/j.1532-950X.2013.12061.x><PMid:24111844>

Itoh H., Hara Y., Yoshimi N., Harad Y., Nezu Y., Yogo T., Ochi H., Hasegawa D., Orima H. \& Tagawa M. 2008. A retrospective study of intervertebral disc herniation in dogs in Japan: 297 cases. J. Vet. Med. Sci. 70(7):701-706. <http://dx.doi.org/10.1292/jvms.70.701><PMid:18685242>

Janssens L.A. 1985. The treatment of canine cervical disc disease by acupuncture: a review of thirty-two cases. J. Small Anim. Pract. 26(4):203-212. <http:// dx.doi.org/10.1111/j.1748-5827.1985.tb02102.x>

Komori H., Shinomiya K., Nakai O., Yamaura I., Takeda S. \& Furuya K. 1996. The natual history of herniated nucleus pulposus with radiculopathy. Spine 21(2):225-229. <http://dx.doi.org/10.1097/00007632-19960115000013> <PMid:8720408>

Kranenburg H.J., Grinwis G.C., Bergknut N., Gahrmann N., Voorhout G., Hazewinkel H.A. \& Meij B.P. 2013. Intervertebral disc disease in dogs - part 2: comparison of clinical, magnetic resonance imaging, and histological findings in 74 surgically treated dogs. Vet. J. 195(2):164-171. <http:// dx.doi.org/10.1016/j.tvjl.2012.06.001><PMid: 22795604>

Levine J.M., Levine G.J., Johnson S.I., Kerwin S.C., Hettlich B.R. \& Fosgate G.T. 2007. Evaluation of success of medical management for presumptive cervical intervertebral disk herniation in dogs. Vet. Surg. 36(5):492-499. <http://dx.doi.org/10.1111/j.1532-950X.2007.00296.x><PMid:17614931>
Mochida K., Komori H., Okawa A., Muneta T., Haro H. \& Shinomiya K. 1998. Regression of cervical disc herniation observed on magnetic resonance images. Spine 23(9):990-997. <http://dx.doi.org/10.1097/00007632199805010-00005><PMid:9589536>

Morgan P.W., Parent J. \& Homlberg D.L. 1992. Cervical pain secondary to intervertebral disc disease in dogs; radiographic findings and surgical implications. Prog. Vet. Neurol. 4(3):76-80.

Olby N. 2014. Tetraparesis, p.271-296. In: Platt S. \& Olby N. (Eds), Manual of Canine and Feline Neurology. 4th ed. BSAVA, London.

Posner L.P., Mariani C.L., Swanson C., Asakawa M., Campbell N. \& King A.S. 2014. Perianesthetic morbidity and mortality in dogs undergoing cervical and thoracolumbar spinal surgery. Vet. Anaesth. Analg. 41(2):137-144. <http://dx.doi.org/10.1111/vaa.12127>

Rossmeisl J.H., White C., Pancotto T.E., Bays A. \& Henao-Guerrero N. 2013. Acute adverse events associated with ventral slot decompression in 546 dogs with cervical intervertebral disc disease. Vet. Surg. 42(7):795-806. <http://dx.doi.org/10.1111/j.1532-950X.2013.12039.X><PMid:23980621>

Russell S.W. \& Griffiths R.C. 1968. Recurrence of cervical disc syndrome in surgically and conservatively treated dogs. J. Am. Vet. Med. Assoc. 153(11):1412-1417. <PMid:5693916>

Ryan T.M., Platt S.R., Llabres-Diaz F.J., McConnell J.F. \& Adams V.J. 2008. Detection of spinal cord compression in dogs with cervical intervertebral disc disease by magnetic resonance imaging. Vet. Rec. 163(1):11-15. <http://dx.doi.org/10.1136/vr.163.1.11><PMid:18603629>

Saal J.A., Saal J.S. \& Herzog R.J. 1990. The natural history of lumbar intervertebral disc extrusions treated nonoperatively. Spine 15(7):683-686. <http:// dx.doi.org/10.1097/00007632-199007000-00013><PMid:2218716>

Santini G., Mazzanti A., Beckmann D.V., Santos R.P., Pelizzari C., Polidoro D. \& Baumhardt R. 2010. Doença do disco intervertebral cervical em cães: 28 casos (2003-2008). Pesq. Vet. Bras. 30(8):659-664. <http://dx.doi. org/10.1590/S0100-736X2010000800009>

Schmied O., Golini L. \& Steffen F. 2011. Effectiveness of cervical hemilaminectomy in canine Hansen type I and type II disc disease: a retrospective study. J. Am. Anim. Hosp. Assoc. 47(5):342-350. <http://dx.doi.org/10.5326/ JAAHA-MS-5604><PMid:21852506>

Seim H.B. \& Prata R.G. 1982. Ventral decompression for treatment of cervical disk disease in the dog: a review of 54 cases. J. Am. Anim. Hosp. Assoc. 18(2):233-240.

Sharp N.J.H. \& Wheeler S.J. 2005. Small Animal Spinal Disorders: diagnosis and surgery. 2nd ed. Elsevier, Scotland. 379p.

Steffen F., Kircher P.R. \& Dennler M. 2014. Spontaneous regression of lumbar Hansen type 1 disk extrusion detected with magnetic resonance imaging in a dog. J. Am. Vet. Med. Assoc. 244(6):715-718.<http://dx.doi.org/10.2460/ javma.244.6.715><PMid:24568114>

Tipold A., Bernardini M. \& Kornberg M. 2010. Spinal cord, p.333-364. In: Jaggy A. (Ed.), Small Animal Neurology. Schlütersche, Hannover.

Tomlison J. 1996. Surgical conditions of the cervical spine. Semin. Vet. Med. Surg., Small Anim. 11(4):225-234. <http://dx.doi.org/10.1016/s10962867(96)80016-8><PMid:9020576>

Weber H. 1983. Lumbar disc herniation: a controlled, prospective study with tem years of observation. Spine 8(2):131-140. <PMid:6857385> 